INTERACTIVE ARTICLE COVER

RUPKATHA JOURNAL

About the Journal

\begin{tabular}{|c|c|}
\hline \multicolumn{2}{|r|}{ About the Journal } \\
\hline Journal DOI & https://doi.org/10.21659/rupkatha \\
\hline Journal Home & www.rupkatha.com $\oslash$ \\
\hline & Scopus $₫$ Web of Science: Emerging Sources Citation Index (ESCI) DOAJ \\
\hline Journal Metrics & CiteScore 2020: 0.2 | SJR 2020: 0.162 | SNIP 2020: 0.193 | JCI 2020: 0.50 \\
\hline \multicolumn{2}{|r|}{ About the Issue } \\
\hline Themed issue & $\begin{array}{l}\text { Volume 4, number 1, } 2022 \text { (January-March) | Contemporary East and } \\
\text { Southeast Asian Literary and Cultural Studies }\end{array}$ \\
\hline Guest Editors & Dr Jeremy de Chavez $\triangle$ \& Dr Zhang Yue, University of Macau, China \\
\hline Issue DOI & https://doi.org/10.21659/rupkatha.v14n1 \\
\hline TOC & https://rupkatha.com/v14n1.php $\oslash$ \\
\hline Peer Review & Under the responsibility of the Guest Editors \\
\hline \multicolumn{2}{|r|}{ About the Article } \\
\hline Title & $\begin{array}{l}\text { From Private Eye to Public "I": The Chinese Filipinos in Charlson Ong's } \\
\text { Hard-Boiled Fiction }\end{array}$ \\
\hline Author/s & Joseph Ching Velasco $\bigotimes$ \\
\hline Affiliation & De La Salle University, Manila, Philippines \\
\hline Author ID & https://orcid.org/0000-0002-7098-8216 \\
\hline Funding & No funding received. Published free of any charge. \\
\hline Article DOI & https://doi.org/10.21659/rupkatha.v14n1.16 Pages: $1-11$ \\
\hline Abstract & https://rupkatha.com/v14n116 \\
\hline Full-text PDF & https://rupkatha.com/V14/n1/v14n116.pdf Ø \\
\hline \multirow[t]{3}{*}{ Article History } & Abstract received: 31 March 2021 | Complete article received: 1 August 2021 \\
\hline & Revised article received: 1 Sept 2021 | Accepted: 4 Sept 2021 \\
\hline & First Published: 05 February 2022 \\
\hline Article Impact & Check Dynamic Impact \\
\hline Copyright & Aesthetics Media Services $\square$ \\
\hline Licensing & Creative Commons Attribution Non-Commercial 4.0 \\
\hline
\end{tabular}

This Open Access article is published under a Creative Commons Attribution Non-Commercial 4.0 International License (http://creativecommons.org/licenses/by-nc/4.0/), which permits non-commercial re-use, distribution, and reproduction in any medium, provided the original work is properly cited. For citation use the DOI. For commercial re-use, please contact editor@rupkatha.com. 
1 Rupkatha Journal, Vol. 14, No. 1, 2022

Research Article

\title{
From Private Eye to Public "I": The Chinese Filipinos in Charlson Ong's Hard-Boiled Fiction
}

\author{
Joseph Ching Velasco
}

Department of Political Science and Development Studies, De La Salle University, Manila, Philippines

\begin{abstract}
Charlson Ong's Blue Angel, White Shadow (2010) is a hard-boiled fiction that revolves around the issues of crime, corruption, and death in a postcolonial Southeast Asian state. Predominantly dark, gloomy, and mysterious, the mood of the narrative establishes a strongly morose reading experience. The narrative world portrayed in the novel is simultaneously sorrowful and somber. Binondo, the historical ethnic Chinese epicenter of the Philippines, is depicted with excessive chaos and moral disarray. I argue that the novel has attempted to reshape the usual form of hard-boiled fiction by systematically interrupting the narrative's serious and cynical tone. More specifically, humor was deployed by the author as a mechanism to intervene in the novel's subscription to the norms of hard-boiled fiction. The novel puts into perspective different facets of Chinese Filipino identity mediated through the Philippine postcolonial landscape. Ultimately, I initiate a discussion on the intersection of Chinese Filipino literature, identities, diaspora, and genre theory. I maintain that Chinese Filipino literature, like the subject of the present inquiry, is borne out of the diasporic experience through collective histories and memories.
\end{abstract}

Keywords: Postcolonialism, Charlson Ong, Hard-Boiled Fiction, Chinese Filipino, Binondo, Manila

\section{Introduction}

Scholars such as Morse (2005), Beyer (2016), and Ball (2017) have made the case that the hardboiled genre, an arguably western tradition, has an iteration different from its original conception in a postcolonial state. Pearson and Singer (2016) maintain that "the detective genre has been intrinsically engaged with epistemological formations that are not simply those of "society" in the abstract [...] but those produced in encounters between nations, between races and cultures, and especially between imperial powers and their colonial territories" (p. 3). I follow Pearson and Singer's (2016) line of thought by looking at how Charlson Ong, a Chinese Filipino writer, reframes the hard-boiled genre in a specific postcolonial context. I look at how his highly regarded novel Blue Angel, White Shadow (2010) hybridizes the hard-boiled genre within postcolonial conditions by incorporating tropes commonly found in the genre. Specifically, I examine how a diasporic context might change the understanding of a detective as a figure in a postcolonial context; more specifically, how the Private Eye (the detective) morphs into a Public "I" (public identity) in the novel. 
I have engaged with a host of studies on Chinese Filipino identity and its representation in literary texts and other cultural productions. My article then follows the insights of scholars such as Velasco (2017), Gonzales (2015), Miao (2021), Hau (2014), Suryadinata (2013), Velasco and De Chavez (2021), and Chu (2010). In "The Contingencies of Chinese Diasporic Identities in Charlson Ong's Speculative Fiction," Velasco (2017) examines Charlson Ong's earlier novel, titled $A n$ Embarrassment of Riches (2000), which primarily looks at the manifestations of hybridity found in the novel as it represents Chinese diasporic identities. Gonzales (2015) puts into perspective how Chinese Filipino identity in Carlson Ong's novels. She argues that Banyaga: A Song of Warpresents and constructs an identity of the Chinese Filipino "in the person of the tycoon [...] who desires and longs to be part of the community" and that the An Embarrassment of Riches presents a ChineseFilipino tycoon that attempts to "subvert the nation" (p. 428). Miao (2020) further argues that in Charlson Ong's works, familial secrets do have a considerable influence in the narrative present.

Hau (2014) broadly examines and rethinks Chinese Filipino ethnicity and identity in the Philippines vis-à-vis nationalism. In particular, she looks at "ways in which changing configurations of politics, economy, society and culture shaped and reformulated the "Chinese Question" at the local, national, regional and global levels" (Hau, 2014, p.35). In a similar vein, Suryadinata (2013) puts into perspective how Southeast Asian nations such as Malaysia, Thailand, Singapore, Indonesia, and the Philippines perceive their ethnically Chinese citizens. He generally concludes that there exists "six types of government policy toward the ethnic Chinese in Southeast Asia: assimilation, acculturation, accommodation, expulsion, genocide and cultural pluralism" (p. 286). In the Philippine context, the Chinese Filipinos are in a complicated position as they continue to be targets of discrimination, government indifference, and crime (Velasco \& De Chavez, 2021). Ultimately, the Chinese Filipinos feel that they have not fully integrated into Philippine society and have been frequently scapegoated for the economic hardships of the country (Chu, 2011). These issues and antagonisms related to the Chinese Filipinos and the Philippine state have been embodied in the novel of Charslon Ong entitled Blue Angel, White Shadow.

\section{Blue Angel, White Shadow: Charlson Ong's Hard-Boiled Fiction}

The narrative is set in Manila, specifically in Binondo (the local Chinatown) and the novel generally evokes a highly cynical environment, filled with pessimism and moral corruption. The novel makes intertextual references to the thrillers of John Le Carré, Ken Follet, and Robert Ludlum. Blue Angel, White Shadow simultaneously unravels a bleak mystery situated in Manila's Chinatown called Binondo and depicts the profound and complicated desires and secrets of the characters. The novel is primarily centered on Inspector Cyrus Ledesma, a detective who was tasked to investigate the death of a lounge singer in a city filled with crime and political intrigue. It is clear in the novel that the character of Cyrus Ledesma is patterned after the hard-boiled detective trope that frequently appears in American Crime Fiction. The narrative starts with the death of Laurice Saldiaga, a 25-year-old lounge singer. This event alarms the regular visitors of the Blue Angel Bar. Laurice was found dead in her bed wearing a red cheongsam (a type of Chinese dress) and a hairpin lodged in her shoulder. This perplexed the whole Chinese Filipino community in Binondo because of the sheer brutality and violence of the murder. Laurice believed that she was meant to be more than a simple lounge singer. 
Before Laurice was murdered, she was strongly associated with three men, namely Antonio Cobianco, Mayor Lagdameo Go-Lopez, and Rey Nadurata who is a dyslexic lounge pianist. Antonio Cobianco and Go-Lopez are childhood friends and both of Chinese descent. Antonio Cobianco, the owner of the Blue Angel, desires Laurice Saldiaga to wear the red cheongsam that was previously owned by Bok Lan. Strangely, Cobianco is fixated and obsessed with the red cheongsam. On the other hand, Lagdameo Go-Lopez yearns for the company of Laurice Saldiaga and he frequently visits the Blue Angel just so he can see her.

With the puzzling state of events surrounding the murder of Laurice Saldiaga, Chief Superintendent Ruben Jacinto sends his nephew, Inspector Cyrus Ledesma, to investigate the case. Ledesma, a Chinese Filipino police officer, was chosen by his Uncle Ruben to take over the case because of his ability to speak Chinese. Despite this seemingly noble cause of solving the murder case, Cyrus' checkered past haunts him and his current career as a police inspector. The Philippine police force is generally depicted in the narrative as a morally corrupt institution that blatantly colludes with known criminals and drug dealers.

When Cyrus was younger, a certain senator's son introduced him to the use of drugs, particularly methamphetamine hydrochloride. In addition to his drug habit, he is known to have a proclivity for violence. Cyrus was expelled from the Chinese school when he was eleven years old for violent delinquency. Consequently, his rough demeanor lands him in Boys' Town, a camp that aims to reform delinquents. During Martial Law, he was incarcerated in a military camp for illegal possession of marijuana. Cyrus is also a member of a fraternity and almost killed a neophyte during an initiation rite. This act lands him in jail again but is freed after a month. Cyrus attempted to take up various tertiary degrees including accountancy, engineering, and merchant marine training but was not able to finish anything. He ended up becoming an insurance broker, a used car dealer, and a real estate agent. He also became involved in the illegal smuggling of lumber.

With the help of Jacinto, Cyrus Ledesma eventually enters the police force. He immerses himself in the corrupt dealings of the Philippine police. On the side, he becomes a hitman for his mostly unknown superiors. In 1998, he kills an Egyptian named Rashid for allegedly being a pedophile. This event has severely affected his comrades in the force, including Rafael Sulit who is reassigned to the mountains where the members of the New People's Army, the military arm of the Communist Party of the Philippines, reign supreme. As a consequence, Cyrus is sent to a detention center for political prisoners instead of the regular city jail for convicted felons. While in detention, he becomes religious in an attempt to keep his sanity and that "religion kept peace in his domain" (Ong, 2010, p. 19). Fr. Javier "Jayjay" Reyes, Cyrus' closest friend, visits him constantly in the detention center. Cyrus Ledesma's ordeal ends when his Uncle Ruben is appointed the Manila Police Director and Jacinto's former student, Lagadameo Go-Lopez, wins the election and becomes a mayor. Cyrus Ledesma is again reinstated in the police force.

Their goal of uncovering the truth about the murder of Laurice Saldiaga also exposes the private mysteries and miseries of the lives of Antonio Cobianco, Robert Cobianco (called Bulldog, a local crime lord involved in the drug trade and underground dog fighting), and Mayor Lagdameo Go-Lopez (a former policeman who became the mayor of Manila). Antonio Cobianco had affair with Anna Cobianco, the mother of Robert Cobianco. Bok Lan arrived in the Philippines from China. Tiak Lan, the husband of Bok Lan, practices ancient Chinese medicine but the Red Guards 
4 | From Private Eye to Public "I": The Chinese Filipinos in Charlson Ong's Hard-Boiled Fiction

of the communist revolution accused him of sorcery and was also forced to confess to his supposed crimes against the Cultural Revolution. Tiak Lan, who lost what remains of his sanity at that point, drowns and dies under the watch of Antonio Cobianco.

While these eccentricities provide fascinating layers to the personal histories of these characters, they are certainly not part of Laurice Saldiaga's murder. Apparently, Bituin, the unassuming waitress that was hired in the Blue Angel was the one responsible for the death of Laurice. It turns out that she died after Bituin withholds Laurice's inhaler from her while she was suffering from an asthma attack. Bituin then panics and attempts to revive Laurice by pricking her shoulder with the hairpin hoping that it will initiate blood circulation again but this, of course, fails. The narrative ends in a climactic scene where it is discovered that Robert Cobianco's dogs are not just used for his illegal fights but are also used as drug mules. Antonio Cobianco finally agrees to sell the property that once stood proud in Binondo to Taiwanese developers. In the end, Bituin escapes the Philippines to rejoin her remaining relatives in Japan without facing justice for the murder of Laurice.

\section{The Narrative of Murder: Detective Fiction and its Humorous Subversion}

Predominantly dark, gloomy, and mysterious, the mood of Blue Angel, White Shadow establishes a strongly morose reading experience. The narrative world portrayed in the novel is sorrowful and somber and Manila is depicted as full of "urban chaos, [partially] devoid of spiritual and moral values, pervaded by viciousness and random savagery" (Malmgren, 2001, p. 71). It is a city built on brothels, illicit drug deals, corrupt policemen and bureaucracy, illegal underground dog fights, and murder. In a setting that is full of moral and political corruption and greed only the tough can survive. Appropriately classified as a hard-boiled detective fiction, the novel focuses on a homicide case, specifically the death of Laurice Saldiaga. In order to propel the narrative forward, Cyrus Ledesma interweaves the seemingly fragmented incidents in the novel to launch a cohesive picture that establishes the rationality of the chain of events. The narrative "foregrounds the actions and adventures of the investigating hero" (Malmgren, 2001, p. 135). In addition, Cyrus Ledesma seems to be a romanticized figure in the narrative as his character was framed to be a man with a mission of determining the perpetrator of the crime.

However, the character of Cyrus Ledesma is far from perfect even though he is the sole stable sign in the narrative. The genre's parameters require hard-boiled narratives to depict murders in a gruesome manner and that the detectives themselves are usually depicted as violent individuals (Yarbrough, 2008). Furthermore, the inspector is an "imperfect agent whose actions lead to murder and mayhem" (Malmgren, 2001, p. 135). Cyrus Ledesma is a morally dubious protagonist who is closely involved with the corruption he is investigating. Here, the narrative portrays Cyrus Ledesma as a strongly flawed individual with damaged morals:

In high school, Cyrus hung out with mop-topped smokers and drinkers but did enough to graduate. His uncle, Ruben, occasionally checked his nephew's arm for needle marks and other signs of drug use. During Martial Law, the thirteen-year-old was hauled off for having a stick of marijuana on him. They shaved his head and sent him home after a week. In college, Cyrus joined a fraternity and was hauled off to jail again after taking part in 
initiation rites that nearly killed a neophyte; he was freed after a month. [...] He'd killed a low-life; they'd have paroled him after a few years for good behavior. Instead, he'd caused a big trouble by killing the man he was tasked to protect, harmed careers and lives. (Ong, 2010, p. 36-37)

Ledesma, therefore, is "part of the problem, the catalyst [that] by his very introduction both provokes murder and solves them" (Malmgrem, 2001, p. 135). The entirety of the narrative shows the entrenched moral disarrays and irremediable sociopolitical and economic ills. As such, Cyrus embodies both antagonistic and protagonistic tendencies and partly triumphs with the given case at hand. At the end of the novel, Cyrus was able to determine who murdered Laurice but nevertheless fails to bring the perpetrator to justice.

Throughout the course of Cyrus Ledema's investigation, the characters that he suspects as the murderer become erratic with the continuous shifting of the blame. Antonio Cobianco who has urged Laurice to wear the cheongsam offers an admission but not of this specific crime of murder. His admission is too vague for him to be brought to justice. On the other hand, Lagdameo Go-Lopez keeps on veering away from the topic of Laurice's murder when interviewed by Rosemarie. In the chapter entitled "Confession," the transfer of guilt from one person to the other is demonstrated:

"So he's confessed, good God," Mayor Go-Lopez nearly shouted as he burst into Director Jacinto's office, seemingly overjoyed. "I knew it was him, saves us trouble. So where is he? In lockup?" [...] Ruben Jacinto nodded. [...] I'm sure what he is confessing to. He's said nothing else other than 'I'm guilty, it's all my fault. It was me... from the start... I planted the seed. (Ong, 2010, p. 171)

It is inherent in the narrative that there is no solid ground to which the truth about the murder is anchored. The characters, instead of acting their natural roles, become reactive and conscious towards the claims they are supposedly incriminated with. In hard-boiled detective fiction, such is a conventional practice in narrative development. Malmgren (2001) maintains:

There is thus no "solid ground" in detective fiction, and no absolute center, no repository of justice, wisdom, stability, or order. The settings are fluid, and the chain of events is the product of hazard and circumstance. The characters in these stories begin by performing elaborate, and sometimes gratuitous, masquerades. Once the detective stirs things up, these characters are reduced to raw improvisations; no longer able to "act," they react, usually in self-serving ways. (p. 74)

As such, Mayor Go Lopez considers the interview with Rosemarie as the perfect encounter to "float his own theory of what transpired that night across the sea of gossip that may soon fill the air, to push away the tide of suspicion should it wash towards his own shore" (Ong, 2010, p. 160).

Despite the violence and chaos of urban Manila in the narrative, the generally pessimistic mood is disrupted and subverted by sporadic placement of humor within the encounters of the characters. Perhaps, this is the technique to which Charlson Ong intervenes in the generic form of this specific hard-boiled fiction. When Rosemarie was called a bastard in the school where she is studying, the humorous encounter between Rosa Misa and Antonio provides a brief subversion of the prevailing cynical ambiance. As a violent response to the classmate of Rosemarie who called 
6 | From Private Eye to Public "I": The Chinese Filipinos in Charlson Ong's Hard-Boiled Fiction

her a bastard, she slams her tin lunchbox on the head of her classmate. This lands her in the assistant principal's office in which Rosa and the school administrator continue to argue. At the house of Antonio Cobianco, where the three convene after the incident, they utter humorous remarks regarding the school incident:

"How dare she say my daughter's not normal? How normal is she? She married a priest, the whore! Stole him from God! And she dares to brand me and my daughter?" "Exseminarian..." "Same thing!" "Is it good to be normal?" Rosemarie wanted to ask the adults but her mother's anger seemed too daunting. "I told you I'd adopt her," Antonio said and Rosa glared at him. "What? Let her use my name... until she grows up, then she can decide for herself. They won't mess with a Cobianco, right, girl?" Antonio patted the girl's head. "Next time, use the underside of your lunch box, it'll hurt so bad she won't even dare tell on you." (Ong, 2010, p. 80).

In another instance, Rosa Misa and Antonio Cobianco have a conversation regarding Rosemarie's plan to go to law school. Rosa is taken aback as Rosemarie has been visiting Antonio without her knowledge. Rosa Misa then distrustfully asks Antonio, "and what have the two of you been planning behind my back?" (Ong, 2010, p. 83). Antonio Cobianco comically retorts, "well, let's see, last time we decided to have you kidnapped and mailed to Palawan for the giraffes" (Ong, 2010, p. 83). Rosa irately replies while glaring at Antonio, "don't be a wise ass, Chinaman. I'm not sure how much law school is going to cost unless she gets a scholarship" (Ong, 2010, p. 83). As can be seen, the seriousness of their conversation is again unsettled by the presence of humor.

Cyrus and Rosemarie have their fair share of comical encounters even at entirely grave moments. Their initially stern discussion about the Unicorn udders, or the potion that Antonio Cobianco cooks, turns out to be ludicrous:

"Once, when I was fifteen. I visited him here, then I felt sick. I felt my head swelling. I saw these glass-like figures floating in through the window and my heart was racing. He roused me from my trance; then he cooked up this bittersweet potion for me to drink. He said it was unicorn... I can't forget that smell." "Trance? You mean you're one of those..." [...] "I'm sure. So you got any more secrets, Misa? Don't tell me... you're waiting for your spaceship... "Fuck you!" she said, throwing a plastic bottle at Ledesma. He caught it with his right hand. "You don't catch me off guard twice," he said shaking his head. "So, might he be giving it to her as well... this unicorn thing? Sounds obscene..." "You have a trash heap for a mind. It's likely the name for an herb, maybe some obscures stuff from China [...] "Aphrodisiac maybe? Super Viagra? They have a billion people over there, after all." "Isn't anything else you think about?" (Ong, 2010, p. 148-149)

Through the occurrence of humorous encounters in the narrative, the usual stern and pessimistic environment is disarrayed. It shows that even a genre as unyielding and hardhearted as hardboiled fiction, such can still be molded to accommodate elements and tropes beyond what readers would expect.

Overall, the narrative partly resists the conventions of the genre as it challenges the underlying assumption on how it should operate. Generally, such fiction is an effective instrument 
of "socio-political critique, using the genre to address issues of class, race, and gender to expose corruption, and to explore the nature of prejudice" (Horsley, 2005, p. 159). It can be argued that the novel also places immense emphasis on some the characters' morality that enforces the milieu of the narrative - of being dark, cynical, and nefarious. Thus, the role of the reader is to weigh and sift through the motive, characters, and circumstances to reach the point where everything appropriately falls into place as designated by the author.

Hard-boiled fiction is generally from the American tradition, and it is the product of modern urbanization (Malmgren, 2001). In addition, this form of fiction does not offer a sense of security in the experience of reading because "it undermines the supposedly necessary connection between cause and effect" (Malmgren, 2001). I argue that Charlson Ong subverts and potentially remaps the American-derived genre of hard-boiled fiction through the use of humor in the narrative. It can also be considered that the narrative is a mockery of the Filipino justice system. In American hard-boiled fiction, the perpetrator of the crime, usually, faces the unyielding hand of justice. It is notable that in Blue Angel, White Shadow, Bituin was able to escape to Japan without facing justice.

Overall, Charlson Ong reworked the genre of hard-boiled fiction in the Filipino context by situating the narrative in Manila with a multicultural range of characters. Furthermore, he creatively intervenes in the generic form of the narrative by deviating from the expectations of hard-boiled narratives. Out of the tradition and contours of hard-boiled fiction; Ong has imbued the novel with Chinese and Filipino elements. In order to redefine the tradition of this genre, the concept of humor has been deployed as a crucial component to simultaneously break the monotony of the hard-boiled narrative.

\section{Binondo as a Diasporic Community of Cross-Cultural Encounters and Multicultural Expanse}

As a cross-cultural hub of diasporic encounters in the Philippines, Binondo is a space where the expanse of multiculturalism is accentuated. The Parian, based on the history of the Philippines, is the zone where there is a predominant Chinese-Filipino population. For the Spanish colonizers, the Parian is a site of colonial control that attempts to limit the movements of the Chinese. Lua maintains:

Under the Spanish Colonial power, La Isla de Binondo was founded as an alcaiceria to ensure continuance of the trade and business, to offer material services to those in Intramuros (Manila). This community of sangleyes, mestizos, and indios thrived and rose to economic and social prominence, and by the late $19^{\text {th }}$ century, became the commercial capital of the Philippines. (Lua, 2007, p. 136)

The evolution of the Parian to Binondo entails the growth of the Chinese diasporic community. Although the Parian encountered fires on several occasions, such is ceaselessly reestablished which then gave birth to Binondo - the ultimate diasporic space of Manila. Knott (2010) describes the nuances of a diasporic space: 
8 | From Private Eye to Public "I": The Chinese Filipinos in Charlson Ong's Hard-Boiled Fiction

Diasporic spaces are not so much 'ungrounded' and 'deterritorialized' structures of economic domination across the Asia Pacific [...] as they are place-centered and networkbased spaces with porous boundaries whose real extents are changeable in association with intra-diasporic contexts and events. (p. 82)

Hence, Binondo localizes the foreign settlers and in turn the settlers contour the diasporic space with their own cultural profiles and upbringing.

In this specific narrative of Charlson Ong, one facet of Binondo is the strong concurrence of the Chinese, similar to the early Parian:

Meo was assigned to Binondo, which he didn't know very well [...] Still, while having his afternoon mami at Hwa An, at the corner of Ongpin, looking for the proprietor Lim, who usually disappeared behind the counter at the sight of taxmen. [...] Meo wondered what it would be like to walk into the main office of Regal Textiles in Juan Luna and ask for Washington Go, though the patriarch seldom went there these days. (Ong, 2010, p. 121)

Binondo here serves as a symbol that signifies Chinese economic endeavors since all of the businesses mentioned are Chinese owned like Regal Textiles by Go and Hwa An by Lim. All of these point to the economic mobility of the Chinese settlers. Binondo, similar to the Parian, is a locale marked for the Chinese to provide service and sell goods. However, a tone of cynicism is invoked against the Chinese in the passage, that is, Lim hides from the taxmen. It shows the rift between the Chinese and the Filipinos.

Another facet of Binondo as portrayed by Charlson Ong is being a multicultural diasporic space. It is a "multi-cultural" space, where various nationalities walk in the streets as if it is the most ordinary thing in the world (Lua, 2007). The presence of Bailey in the narrative highlights this aspect of Binondo. Considering his background, he is originally from Boulder, Georgia; then he enlists in the US army under the command of General Clair Chennault and fights the Japanese in China. In Binondo, he nonchalantly stays in an apartment next to a printing press. Furthermore, after he has been discharged from the service, he literally roams the streets of Manila and plays music in bars:

When I got to Manila after the war, I knew I was never going back on that ship. I roamed the streets, played in bars. One day, I got into a restaurant, didn't have enough to pay my noodles. The Chinaman was all over me, shouting, said he'd call the MP. 'Go ahead, call the damn MP,' I said, I knew he was calling me a black devil or some shit like that. I yelled, 'a fucking flying tiger!' He suddenly stopped. It was like he'd seen a ghost and he rushed away. I thought I'd scram but he was right back with another bowl of noodles. (Ong, 2010, p. 74)

This encounter is suggestive of ethnic multiplicity in Manila. Lua (2007) argues, "the presence of a diasporic community in a plural society evokes the sense of familiarity, which in turn creates an atmosphere of stability in the eye of the beholder" (p. 137). Extending the point raised by Lua, Binondo's sense of being a familiar district of transnational gathering enables the localization of the diaspora - of not simply being exclusive to the Chinese but a host of different ethnicities. Binondo as a space for diasporic interaction, therefore, goes "beyond simple oppositions between 
the national and transnational, the rooted and the routed, the territorial and the deterritorialized" (Knott, 2010).

From transnational movements, local movements to Binondo also occur particularly in the case of Laurice and Bituin. Initially residing in Malabon, her commute to the Blue Angel in Binondo is not necessarily worth the trouble. Eventually, she moves in and stays in the vacant room at the bar owned by Rosa Misa. As for Bituin, she has been hired as a waitress with the ultimate goal of leaving the Philippines for Japan to search for her relatives. She narrates her initial foray to Manila and even Binondo:

"I came to Manila two years ago. I've been living with relatives in Paco," the girl answered with a Waray lilt, and Rosa saw how a tinge of brown on her hair and eye shadow, some rouge perhaps, could go a long way. She was no head turner for sure; she was too petite for the buxom bombshell set - a shade under five feet - but pretty in a homespun way. (Ong, 2010, p. 95)

These local movements within Binondo add shade to the concept of an imagined community, where the local and the transnational converge. It can be argued that Binondo is a community built on multicultural encounters and even colonialist aggression. Furthermore, Binondo as a diasporic locale can be envisaged as an imaginative geography and history which dramatizes the difference between what is close to it and what is far away (Hall, 2003, p. 241). Both Stuart Hall and Benedict Anderson's points veer towards labeling Binondo as a conceptual imagination - of ironically putting together what seems to be far and near together. Consequently, it further stabilizes the circulation of individuals that is present in the locale.

What is the relation of Binondo to the identity formation of the characters, including the Chinese, which revolves within the locale? Through this space, "creolizations and assimilations and syncretisms [are] negotiated" (Hall, 2003, p. 243). Hence, identities are mediated through subject positions. As depicted through the existence of the Chinese, Filipinos, and even the Americans in the narrative; such entails that diasporas require the "recognition of a necessary heterogeneity and diversity" (Hall, 2003, p. 244). Their identities are not based on their essences or their origins, but it is thoroughly shaped through their participation in the imagined community. Furthermore, "it conveys [...] the instability, the permanent unsettlement, the lack of any final resolution" of the constructions of identity (Hall, 2003, p. 238).

As a melting pot of culture, Binondo is a space that is strongly associated with the Chinese and the diaspora. By establishing themselves as individuals of economic mobility, the Chinese have found their initial niche in this specific multicultural space. However, they are somewhat perceived a necessary but undependable ally in nationalist endeavors. This claim is quite contingent with respect to the heterogeneity of the Chinese living in the Philippines. Their encounters with individuals hailing from different backgrounds enable the negotiation of identities. Stuart Hall maintains that "cultural identities are the points of identification, the unstable points of identification or suture, which are made, within the discourses of history and culture" (Hall, 2003, p. 237). The Chinese Filipinos, as diasporic beings, ultimately transcend the boundaries of identity that come with their essentialized past and their unrooted present. It is through this discontinuity that allows them to create new spaces of becoming in a wide multicultural expanse. 


\section{Conclusion and Future Directions}

In this article, I examined Charlson Ong's Blue Angel, White Shadow and inspected its deviations from the usual form of hard-boiled fiction. The novel has attempted to reshape the usual form of hard-boiled fiction by interrupting the narrative's serious and cynical tone. Humor has been deployed as a hybridizing mechanism for this specific novel. Noticeably, hard-boiled narratives exude a dark and cynical disposition which gives the readers a very morose reading experience. However, in this case, humor tends to be the deviation from the narrative conventions hard-boiled fiction. Strategically situated among the encounters of the characters, the cynical ambiance that is prevalent is disrupted. It shows that even a genre as unyielding and hardhearted as hardboiled fiction, such can still be molded to accommodate elements beyond its usual parameters while still retaining and enforcing some of its conventions. Overall, the narrative partly resists the norms of the genre as it challenges the underlying assumption on how it should operate. Furthermore, the closure of the narrative deviates from the traditional form of letting the criminal face justice. In the narrative, the criminal escapes without harm or facing justice.

The novel negotiates the complexities of identity and diasporic locations by shifting the genre and imbuing it with new forms of meaning. The narratives of Charlson Ong are quite selfreflexive, meaning it also exhibits the author's means to negotiate Chinese Filipino identity. He uses forms and elements of the novel to expose the rifts and junctions of what it is to be Chinese Filipino. The hybrid Chinese Filipino cultural identity and the hybridized forms of his narrative fully render the complexity of the diaspora in its most vivid appearance.

This present inquiry on Charlson Ong's novel shows multiple facets of Chinese Filipino identities as mediated through fiction. More specifically, what the present article does is commence a productive discussion on Chinese Filipino literature, identities, and the diaspora. It is therefore recommended that further explorations be done on the literary and cultural production of Chinese Filipinos. I maintain that Chinese Filipino literature is borne out of the diasporic experience which touches upon interrelated issues of diasporic history, shared memory, and diverse identities.

\section{Acknowledgement}

I would like to acknowledge Fatima Foz for her editorial assistance in the development of this article.

\section{Declaration of Conflict of Interests}

The author(s) declared no potential conflicts of interest.

\section{Funding}

No funding has been received for the publication of this article. It is published free of any charge.

\section{References}

Ball, T. S. (2018). Sof'town sleuths: The hard-boiled genre goes to Jo'Burg. Cambridge Journal of Postcolonial Literary Inquiry, 5(1), 20-35. https://doi.org/10.1017/pli.2017.38 
Beyer, C. (2016). "The third Ireland": Inheritance and postcolonialism in Irish crime writing. Journal of Commonwealth and Postcolonial Studies, 4(1), 61-81.

Chu, R. T. (2011). Strong(er) women and effete men: Negotiating Chineseness in Philippine cinema at a time of transnationalism. Positions: East Asia Cultures Critique, 19(2), 365-391. https://doi.org/10.1215/10679847-1331760

Gonzales, G. G. (2015). The alien, the citizen, and the triumphant capitalist. Kritika Kultura, (25), 426-466.

Hau, C. S. (2014). The Chinese Question: Ethnicity, Nation, and Region in and beyond the Philippines. NUS Press.

Hall, S. (2003). Cultural identity and diaspora. In. J. E. Braziel \& A. Mannur (Eds.), Theorizing Diaspora (pp 233-246). Blackwell Publishing.

Horsley, L. (2005). Twentieth-century Crime Fiction. Oxford University Press.

Knott, K. (2010). Space and movement. In. K. Knott \& S. McLoughlin (Eds.), Diasporas: Concepts, Intersections, and Identities (pp. 79-86). Zedd.

Lua, S. (2010). The repeating Parian: Tropic positions of Chinese-Philippine fiction in English. In E. Thumboo \& R. I. Sayson (Eds.), Writing Asia: The Literature in Englishes (pp. 129-145). Ethos Books.

Malmgren, C. D (2001). Anatomy of Murder: Mystery, Detective, and Crime Fiction. Bowling Green State University Popular Press.

Miao, C. (2020). Hope beyond disappointment: A reparative reading of Charlson Ong's Of That Other Country We Now Speak. Rupkatha Journal on Interdisciplinary Studies in Humanities, 12(5), 1-6. https://dx.doi.org/10.21659/rupkatha.v12n5.rioc1s21n3

Morse, R. (2005). Racination and ratiocination: Post-colonial crime. European Review, 13(1), 79-89. https://doi.org/10.1017/S1062798705000086

Ong, C. (2010). Blue Angel, White Shadow. University of Santo Tomas Press.

Pearson, N., \& Singer, S. (2016). Detective Fiction in a Postcolonial and Transnational World. Routledge.

Suryadinata, L. (2013). Southeast Asian government policies toward the ethnic Chinese: A revisit. In C. Tan. (Ed), Routledge Handbook of the Chinese Diaspora (pp. 274-289). Routledge.

Velasco, J. \& De Chavez, J. (2021). Enduring fears: The monstrosity of Chinese Filipinos in Chito Roño's Feng Shui (2004). Asian Ethnicity, 1-13. https://doi.org/10.1080/14631369.2021.1941754

Velasco, J. (2017). The contingencies of Chinese diasporic identities in Charlson Ong's speculative fiction" Kritika Kultura, (29), 340-362. http://dx.doi.org/10.13185/KK2017.02916

Yarbrough, S. D. (2008). Hard-boiled detectives. Critical Survey of Mystery \& Detective Fiction, 1-9.

Joseph Ching Velasco, PhD is Associate Professorial Lecturer at the Department of Political Science and Development Studies of De La Salle University, Manila. He is the current Managing Editor and former Editor-in-Chief of the Asia-Pacific Social Science Review. He is pursuing further studies in international relations and public policy at the University of Macau. His works have appeared in journals such as Asian Ethnicity, Kritika Kultura, and Pertanika Journal of Social Sciences and Humanities. His research interest includes Chinese Filipinos, Sino-Philippine Relations, Work Ethics, and Burnout. 